\title{
13. Courtesy and Method in Ethnography ${ }^{1}$
}

\author{
Alexander H. Bolyanatz
}

Although I did not 'believe' the story, courtesy and method naturally obliged me not to try to disabuse them of their belief. (Tuzin 1997:96)

Don Tuzin was, among his many other virtues, unerringly gracious and polished. Those fortunate enough to have known him will have their favourite anecdotes about how he gently corrected those in error or deflected indignity from a deserving target. The denizens of Ilahita village were no strangers to Tuzin's magnanimity. This is evidenced over and over in The Cassowary's Revenge (1997), his poignant memoir of his return to Ilahita in 1985 after a 13year absence.

In this book, Tuzin weaves a remarkable account that begins in 1969 when he first arrived at Ilahita, moves through an interlude in (mostly) the United States, and concludes back at Ilahita in the mid-1980s. Perhaps 'conclude' is not the right word here. If Revenge teaches anything, it holds the lesson that sometimes stories, and their mythopoeic meanings, are amenable to continuous revisionwhat Tuzin refers to as 'the fluid nature of living myth' (1997:131). When I first met Don Tuzin a few months after his final return from Ilahita, it was certainly true that the meaning(s) of his fieldwork in Ilahita - both instanceswas consistently analysed and plumbed for deeper and more meaningful insights. So 'conclude' is a rather inadequate - if not downright inaccurateway of describing the extensive Tuzin-Ilahita association as represented through the final page of Revenge. Like the 'unfinished' (Tuzin 1997:96) story of Nambweapa'w, told and retold, interpreted and reinterpreted, The Cassowary's Revenge does not really end. Like the story of Nambweapa' $w$, in which new elements were added to fit contemporary realities, so The Cassowary's Revenge has a reality beyond its last page - a reality that is relevant for anyone engaged in the ethnographic endeavour.

I should explain myself. I conducted doctoral research under Don's auspices among Sursurunga speakers at Tekedan village in New Ireland Province, Papua New Guinea, from late 1989 until early 1992. I returned six years later for several weeks during the summer of 1998. My reading during that stint of fieldwork included the then-recently published The Cassowary's Revenge. In

1 This chapter has benefited greatly from the comments of Kevin Birth, Mardelle Fortier, David Goldberg and Marie Tenzinger and two anonymous reviewers. Remaining shortcomings can be traced to me. 
many respects, in the same way that Nambweapa'w shaped Don's experiences in Ilahita and beyond, The Cassowary's Revenge has affected the way I understood (and continue to re-understand) myself in relation to the Sursurunga-speaking folks on southern New Ireland and the ethnographic endeavour during that 1998 field trip and the six field sessions I have conducted since then. Don's notion of prophecy as 'insight' (1997:99 ff.) in relation to the Nambweapa'w story has never really been absent as I think about how I relate to the Sursurunga, and they to me.

Before moving on, I should ensure that my references to the story of Nambweapa'w and The Cassowary's Revenge are meaningful to the reader. My recap begins with the story of Nambweapa' $w^{2}$ and its cultural counterpoint: the secret men's cult known as the Tambaran. ${ }^{3}$

Nambweapa' w was a cassowary who was tricked into living as a human femalewife of the first man, and mother of all humanity. Years later, she discovered that she had been duped and, in an act of vengeance, murdered her husband, the first man. The youngest child of their union - a son — was believed to have been the only one not to have squandered the good life that Nambweapa'w had created for her offspring. He came to be understood as the font of the United States ('America') and all its wealth. The Ilahita Tambaran men's cult (like the myth of Nambweapa'w, a nineteenth-century import into the area) was something of an ideological antithesis to Nambweapa'w. The Tambaran manifested male dominion over women that was rooted in women's not knowing (ostensibly) that the eerie sounds - and the concomitant legitimacy of male hegemony-coming from the spirit house were in fact merely man-made.

As the influence of the Tambaran waned in the face of Western education and the influx of cash after World War II, power and prestige hierarchies were scrambled. Exogenous social movements came and went, some finding the soil of Ilahita too parched or filled with weeds to take root. One movement that did take root was a form of charismatic Christianity - led primarily by women and known as the Revival - prior to Tuzin's second stint at Ilahita. Months before his return, a number of men caught up in the Revival 'spilled their guts' about the Tambaran (conceptually reconstituted as the work of Satan), effectively killing the Tambaran - an act mythopoeically foreshadowed by Nambweapa' w's act of homicide. The end of one secret resulted in Nambweapa'w's husband's death; the end of another constituted the death of the Tambaran. The twin male defeats were noteworthy.

2 The complete version of the story can be found in Tuzin (1980:1-8). A synopsis can be found in Tuzin (1997:69-71). My account here is thus a synopsis of a synopsis.

3 Following Tuzin's convention, I capitalise Tambaran throughout. 
Don's reappearance just months after the Great Disclosure was laden with local meaning(s) tied to the now-emasculated Tambaran. For one thing, his return had been the subject of a deathbed prediction on the part of an Ilahita villager named Gidion three weeks before the arrival at Ilahita in 1984 of a letter Don had sent informing everyone of his intention to return in 1985. For another thing, his interest in and appreciation of the Tambaran had been unmistakable 13 years earlier. And was he not the scion of Nambweapa'w removed to America, finally come to take all of his distant cousins who were stuck in exile at Ilahita into a New World? In his words, the peculiar combination of events included

the suspicious coincidence of [my return] with the collapse of the Tambaran, the supercharging of Ilahita's atmosphere with millenarian expectations, the death of Gidion, and the coming to life of Nambweapa' w's old tale of retribution and masculine woe. It was not so much my original arrival in Ilahita that had stirred apocalyptic thoughts (at least not for long); it was my return from America... amid the agitated conditions of the moment, that created all of the commotion. (Tuzin 1977:132, emphasis in original)

The commotion Don refers to is one that any ethnographer would just as soon avoid if given the choice. After all, the point of ethnography is to report salient cultural events, not create them, let alone star in them-again, if given the choice. The besetting quandary of ethnographic fieldwork is that such a choice is rarely, if ever, offered. Tuzin summarises:

With each retelling, Nambweapa'w's story remolds itself to changing circumstances, churning itself into a remarkably coherent jumble of older and newer meanings. The detail of the youngest brother's departure 'for America', with its millenarian overtones, dates from the period of World War II. But it was apparently not until my first arrival in 1969 that the significance of a mythic connection with America began to be realized. And it was not until the announcement in 1984 of my return, that the significance of the original visit was realized. Prophecy works that way - by remembrance and revisitation. Today's events fold back upon memories of yesterday and, by a Proustian alchemy, transfigure them. Isolated fragments from the past become realized as significant objects of intentional meaning, animated and integrated with the present. At the core of this process of remembering is an aesthetic illusion: both for individuals in their ways and cultures in theirs, it is the illusion of the self finding itself in memory. (Tuzin 1997:156)

'The illusion of the self finding itself in memory' is a provocative turn of phrase. I take it to mean (not that this is its only meaning) that one's sense of continuity - the connection between the past and the present-is the 
fabrication of the selective use of memory. In other words, one's selective, filtered, contingent memory of yesterday gives the impression that there is a permanent link between those memories and one's experience of today. And, it goes without saying, the memories are not necessarily shared by others. This generates a matched set of questions: who am I to others; and who are others to me? For a cultural anthropologist, these are important considerations, since interaction with people who are profoundly 'Other' approaches a sine qua non. Clearly, Don's new insights about his recollected experiences at Ilahita fit these questions, as do the local understandings of the events surrounding Don's return.

This seems like a good place for a short hiatus in which to examine Don's sense of his own significance vis-a-vis the collapse of the Tambaran. In some respects, there is little reason to doubt Don's overall sense of things as reported in Revenge, since those who knew him would find a concocted narcissistic fantasy to be simply unimaginable. But there is another reason to assume that Don's portrayal of his own centrality is not inaccurate: a tendency (not unique to Melanesia, but certainly well represented there) to explain phenomena in terms of the unusual, the atypical and the anomalous. Examples are easy to find. In the early 1990s, a trio of Australians was sea kayaking just a bit offshore from Tekedan. After they had departed, I was asked if I thought war was imminent. Stunned by the non sequitur, I asked my aged interlocutor about the source of his question. He told me that just prior to the Japanese invasion in 1942, three boats appeared briefly offshore, heading in the same direction as the kayaks had. An ethnographer in a Melanesian community is an anomaly if there ever was one, so it should be no surprise to read Joel Robbins' account (this volume) of an incident in which a pair of new gloves found in the forest was assumed either to be his (they were not) or to portend a bright new future. Given the import of the Tambaranwe are way beyond the scale of a pair of gloves here-in Ilahita life, it is not outrageous, to me at any rate, to imagine that Tuzin's report of his own salience is not exaggerated.

So, when it came to understanding that confluence of events in 1985 Ilahita, local eschatologies varied, and different people drew different conclusions, but the upshot is unmistakable: ethnographers, whether they know it or not, and in ways they cannot predict or control, become part of local lore. And now, finally, I can point to the epigraph for this chapter. It was the story of Nambweapa'w that Tuzin did not 'believe', and it was his own decency, along with his anthropological instincts - 'courtesy' and 'method', respectively-by which he explains his letting pass the opportunity for refutation.

Since I am going to allude to courtesy and method often in this chapter, it is worth taking a moment to look more closely at them. 'Courtesy' here is really just a kind of civility, which is to say a reticence to draw attention to another's 
deficiency. This is not quite the same as the philosophical notion of 'charity', since that stance requires one to assume truth and rationality on the part of the other and Don is clear that he does not assume this for Nambweapa'w. Indeed, he notes that he 'would have to be crazy, credulous, or exorbitantly relativistic' (1997:100) to presume a face-value truth and rationality when it came to the Nambweapa'w account.

By 'method' here, I refer to the ability to gather data - to have access to people and to events - and to the openness of people when talking to the anthropologist. Together, the two constitute a significant segment of that slippery notion: rapport. Clearly, Don was mindful of the fieldworker's awareness that 'how much, or how little, to disclose...affects relationships with informants, especially in cases where full disclosure would expose a clash of values' (Ranson 2005:110).

A closer reading of the phrase might almost make courtesy and method seem joined, as in 'courtesy-and-method obliged me not to disabuse them of their belief'. Such a usage implies that the boundary between the two is indistinguishable or at least irrelevant. Indeed, that is how I first read them: politeness creates or allows opportunities for gathering information. Likewise, a lack of politeness is almost certain to limit opportunities for gathering information. The strong positive correlation between the two, and the intuitive causal connection, certainly makes them seem, as far as how they operate in the field, fundamentally the same, and this conflation of the two was how I used to think about my own fieldwork in 1989-92 and then again in 1998. I no longer, however, see these two - courtesy and method — as inextricably linked.

Courtesy and method have become detached for me as the answers to the questions 'who am I to the Sursurunga people?' and 'who are the Sursurunga people to me?' have changed. Here is how I used to think about it: when an anthropologist is civil and polite to people at her or his field site (even to the point of not wanting to disabuse people of their beliefs) then one is truly an ethnographer. This is because in order to be an ethnographer, one has to be civil and polite - to my mind. It is almost as if I signal that I am in a data-gathering mode when I exercise courtesy; or that by exercising courtesy, I maintain the possibility of data gathering in the future. When I am short-tempered and rude, or, less extremely, when I speak my mind, even if it rejects what a local person thinks, what am I then-a poor ethnographer or not an ethnographer at all? And if not an ethnographer at all, how then should I see myself when I am on New Ireland? More to the point, how do they see me? From both perspectives, when courtesy - in the form of not wanting to disabuse others of their beliefsis in short supply, the question is: what have I become? Since first reading The Cassowary's Revenge, I have come to recognise that my answer to that question has changed since I first set foot on New Ireland in 1989. 
A significant chunk of Revenge is Don answering the what-have-I-become question. What he had become, of course, was the result of what courtesy and method had inadvertently and serendipitously set in motion - or at the very least, failed to eradicate: the besetting 'commotion' that struck Ilahita in the mid-1980s. And what he had become had spun wildly out of control, at least from his own perspective.

There is no blame here. This sort of thing happens when and where cultural anthropologists work - very much an occupational hazard. The irony is, of course, cloying; courtesy and method-which in Tuzin's case meant being a decent chap and a crackerjack anthropologist-generated a seriously sticky situation. Imagine for a moment if Don had said, immediately upon hearing the tale of Nambweapa'w, 'Folks, that is just the silliest thing I have ever heard. Only a nitwit would believe such nonsense.' There would, of course, have been no perfect eschatological storm years later. And there probably would have been no Ilahita in the ethnological consciousness of anthropology either. We go, we work, we interact. And we are incorporated - that is, memories selected from the past create an anthropologist in the minds of members of the local community that might not, in fact probably cannot, be the anthropologist's own sense of self in relation to that community. The opposite is also true: the returning anthropologist's selective memories of people and events shape how subsequent fieldwork unfolds. It goes without saying that the anthropologist who does not return never has to deal with these issues. In the context that we are discussing here, making no attempt to debunk other people's beliefs is good fieldwork and virtuous humanity. But upon returning, the consequences of this omission when it comes to the questions of 'who am I to them?' and 'who are they to me?' can be profoundly unpredictable, as Revenge chronicles.

I left New Ireland in March 1992 in order to write and defend my doctoral dissertation (Bolyanatz 1994). At that time, I expected to return; I was not sure when, but I did not want my relationships with many of the Sursurunga speakers I had come to know to be terminated. As evidence to others - and myself - that I did expect to return, I purchased a piglet and asked Towor (like most of the names in this chapter, a pseudonym) to raise the pig for me. I gave him some money for expenses and told him that I would compensate him later for any other costs, and he agreed. My plan was to use the pig as a springboard to become involved in the exchanges that culminated in the sequence of mortuary feasts (see Bolyanatz 2000). I imagined that I would visit New Ireland many times over the rest of my life, and I hoped that my involvement in the network of pig exchanges would compensate for the infrequency of my visits.

Towor had become a neighbour over the final year or so of my initial (1989-92) fieldwork, having moved from his natal village, 15 minutes or so away, to mine. Married to a woman of the matriclan into which I had become 'adopted', he was 
my 'father' and I his 'son'. He became one of my primary sources of information as I delved more deeply into the sequence of feasts in honour of the deceased. More than most people, Towor made frequent requests (for matches, soap, tobacco, kerosene), which, while mildly annoying, seemed not unreasonable to me given the fact that I relied on him more than I did most people.

When I returned in 1998, I discovered that Towor had returned to his natal village. 'He stole your pig', I was told shortly after my return by Tohom, who was, in many ways, my closest friend on New Ireland. Tohom was Towor's wife's sister's son, my Tokbol matriclan 'brother'. When I asked Tohom for elaboration, he told me that Towor had-following local convention — sold the pig for cash to a group that needed one in order to sponsor a mortuary feast. Tohom reported that he had reproached Towor, reminding him that he (Towor) had been serving as the pig's custodian on my behalf. But Towor had a reputation as something of a sorcerer, so Tohom felt that he could not push my case very far, knowing that I- as a waitskin ('European') and therefore virtually impervious to sorcerycould escalate the protest if I wanted to.

Towor's penchant for sorcery was something of a revelation to me. When the subject had come up, he had named others as sorcery adepts, and I had no record of others naming him in the early 1990s. But I cannot say that I was shocked upon hearing of his reputation in 1998. Six years' worth of perspective had made me realise that Towor was not, in spite of his helpfulness to me, what anyone would call a 'nice guy'. He had at times been, in fact, a rather nasty sort. This realisation - crystallised for me as Tohom reported Towor's malfeasancegenerated a number of questions about my final months those half-dozen years earlier. Why had no-one ever mentioned Towor's reputation to me? How could I not have known this before? (What kind of ethnographer was I, anyway?) Or was this just Tohom's convenient way of dodging an uncomfortable confrontation? At the time the questions that I did not ask (the reading of Revenge being perhaps too proximate to glean important lessons) were 'who has Towor become to me?' and 'who have I become to Towor?'. Memory was re-filtered and revision took place. I probably understood him and his fundamental meanness better in 1998, but I needed to understand him as benevolent in 1991-92.

I stopped by Towor's house within a couple of days of getting back. We caught up with each other; I showed him pictures of my family-everyone six years older than when he had last seen them-and he commented on how the kids had changed. I had a feeling that he was not going to bring up the pig. And I knew that it would be rude for me to mention it directly. Courtesy and method, I guess. I waited for the conversation to move towards a related subject but it never did. Thus ended my reunion with Towor. 
In the ensuing days and weeks, I proceeded with my work. I wanted to revise my dissertation into a publishable monograph on mortuary feasting and there were some gaps to fill and some clarifications to make that could only be done on site. And there were the usual happenings that will be no surprise to any fieldworker. Topakta, an influential leader, had died several weeks before my arrival; the feud over where he was to be buried was still echoing, and I found myself caught up in that. I discovered and explored a new (to me) means of resolving disputes by means of an extravagant offer of food that, in principle, compels an antagonist to abandon her or his quarrel. I passed through Towor's village now and then, managing to avoid his house for some time.

After nearly three weeks, I had a chance conversation with one of Towor's sons, and he mentioned that Towor wanted to see me. Even though Towor's house was only 15 minutes away, it was another couple of days before I found the time to walk over for a visit. I was not necessarily proud of myself for engaging in that sort of gamesmanship, but who was he to summon me? He could wait until I got around to it. Then again, my debt to him was surely incalculable? With significant help from his insights, I had been able to later write and defend a doctoral dissertation. I had a comfortable academic job. Why was I being so difficult? Courtesy and method, indeed. Was he going to mention the pig? Was an apology forthcoming? Had gathering data somehow become secondary to another agenda? And had I so marked that change by a decline in courtesy? What had I become: a poor ethnographer or not an ethnographer at all?

When I arrived, we sat outside the house and chatted briefly before he told me that since he did not know how long I was going to stay, he wanted to make sure that he saw me before I left so that he could give me what amounted to a shopping list: reading glasses, a shirt, and a pipe. I said that I would see what I could do, mentioned that I was not sure of exactly when I would be back, and that my suitcases were usually overfull anyway. He said he understood and mentioned, as I stood up to leave, that his matrilineage was sponsoring a small mortuary feast the day after next, and that I should be sure to come and bring my video camera.

As I walked back to Tekedan village, I realised that this was about as close as I was going to get to compensation for my pig. At significant cost to him, I was going to be able to participate in another feast and get some footage of it. ${ }^{4} \mathrm{I}$ discovered afterwards from others that the planning for this feast had occurred in a rush, and it became clear that the situation between us had accelerated the timing of this feast. I also realised that his request for reading glasses, a shirt and a pipe was not just a shopping list; he did want to know when I was going to leave, but only in order to make sure that I would still be there on Saturday and

4 In fact, I had trouble with the microphones and ended up with soundless footage, to my great frustration. 
that he should go ahead with the feast. He had orchestrated a return to a better time for us by precipitating a feast while I was still there. Memories of those halcyon days of 1991-92 rushed back - for both of us, I daresay. Courtesy and method? I was not as courteous as I might have been, but I had not pushed on the matter of the pig, so I was, I suppose, courteous enough, and courtesy and method were certainly at the core of the adjustment of memory for both of us. I was still an ethnographer. I was still gathering data.

It was five years before I made it back to New Ireland again - this time, in 2002. Although they had been a year earlier, the attacks of 11 September were on the minds of many people when they saw me, and it was often the first thing people wanted to talk about. Was I near any of the destruction? (No.) Did I know anyone who had been hurt or killed? (No.) Had America captured Osama bin Laden yet? (No.) Did I know any Muslims? (Yes.) Was I afraid of them? (No.)

The primary purpose of this field trip was to procure data that were part of an explicitly comparative project - on perceptions of physical attractiveness (Fessler et al. 2005). It was the first of a series of large-scale comparative research efforts that I have joined in which Sursurunga speakers of New Ireland constitute but one of many data sets. More salient in some ways, however, were the conversations I had with Tohom, who was becoming very sick.

Just a couple of years older than me, Tohom had lost a lot of weight and looked terrible. He said that he had seen many doctors, and no-one seemed to be able to help. He wondered aloud whether he had been ensorcelled by Towor, his 'father'. Indeed, Tohom said that he no longer slept in the same place on consecutive nights so that Towor's supernatural powers could not find him. I nodded sympathetically. Courtesy and method? Not really.

It was here where I began to see courtesy and method become decoupled. I said nothing to Tohom about the rationality of his fears (courtesy) but not because I necessarily wanted any information from him (method). Indeed, I found myself not wanting to gather data on this case; it was hard to hear about Towor's malevolence as well as about Tohom's anxiety - not to mention Tohom's debilitating illness. I had been courteous but not for the sake of method; and clearly, in my reticence when it came to gathering data, I was being a poor ethnographer in this case.

I did not see Towor in 2002; he was engaged in wage labour at a plantation elsewhere in the province. But I found that some ambivalence towards him resurfaced as memories filtered back and I reconstituted him in my mind yet again. Tohom would suspect him as the source of his illness only if there were some sort of problem between the two of them - real or imagined. And because I liked Tohom, I mentally defaulted to his side of whatever conflict there might 
be. I asked him what he might have done to provoke Towor's antipathy and he responded that he was innocent of any wrongdoing when it came to Towor. Towor was, after all, his 'father'; therefore, he could only do such a thing because he (Towor) was, at his core, a bad guy. ${ }^{5}$ I could not, of course, disagree, and my concurrence had little to do with either courtesy or method.

In 2003, I returned to New Ireland as part of another project, in which economic experimental games were played cross-culturally (see Barr et al. 2009; Berbesque et al. In press; Bolyanatz 2010; Henrich et al. 2006, 2010; Marlowe et al. 2008). Tohom was not any better, but he was no worse, so at least the downward trajectory of his health had been mitigated. Towor was back from the plantation, but I did not have much reason to see him. In the middle of 2003, the ubiquitous topic of conversation around the area was vanilla. Vanilla was going to be the cash crop to put the area on a solid economic footing. Copra was always going to be there, even if prices were down. And coffee had failed. ${ }^{6}$ Cacao was currently king, but most people did not have the kind of extensive cacao holdings that would bring in a significant amount of cash. Besides, smallholders had to compete with large plantations just to the north, so cacao was not going to be the long-term answer.

Vanilla, however, was to be the way out of economic stagnation. Apparently, in early 2003, an agricultural expert had visited the region, taken soil samples and proclaimed that southern New Ireland was ideally suited for producing commercial-grade vanilla. Consumer concerns in industrialised countries over cholesterol had significantly affected copra prices a generation earlier, leaving copra with its depressed prices and cacao as the best-really only-ready sources of income. Vanilla stems, though, could be purchased for next to nothing, and vanilla orchards began to spring up. Vanilla vines require some shade and trees to climb, and they have to be watered regularly, especially when young. My 2003 survey showed that nearly two-thirds (16 of 25) of the households at Tekedan village had planted at least some vanilla. The median number of vanilla plantings for all households - including the nine that had not jumped onto the vanilla bandwagon - was 10. Of those households that did begin to cultivate vanilla, the mean number of plants was 164 . Vanilla prices had soared just recently, and the passion was palpable.

The enthusiasm over vanilla seems to have engendered other enthusiasms. The expected economic boom made some folks look at the big picture. New Ireland,

\footnotetext{
5 Grammatically, Sursurunga has three noun classes, each of which takes different kinds of possessives. A person's character or true being is one's ninsán (the á in Sursurunga is the schwa sound), and is in the same noun class as consanguineous kin, body parts and intrinsic features such as shadows. Nouns in this class are immutable. So when Tohom refers to Towor's ninsán as bad, he implies that he always was and always will be bad.

6 See Bolyanatz (1998) for a history of cash cropping in the Sursurunga region.
} 
relative to other provinces in Papua New Guinea, was not poor, and was going to get richer. New Irelanders held important posts in other parts of Papua New Guinea, which was taken as evidence of a burgeoning elite. Indeed, a former Prime Minister, Sir Julius Chan, hailed from Huris village, just a 45-minute walk from Tekedan. And yet, people said, New Ireland's wealth was being squandered on the rest of Papua New Guinea: more money, people and resources such as gold from the mine at Lihir were going out than were coming in. Perhaps it was time for New Ireland's independence. At first, I did not take the secessionist talk seriously, thinking that this was just one more men's house conversation that drifted off into hyperbole as it wound down. But by the third time the topic came up, it was quite clear that, as unrealistic as it might be, there were some people who imagined a nation-state comprising the Bismarck Archipelago. The relative merits of including Manus and/or Bougainville were debated. The transition of the local constabulary into an army was discussed. At some level, I realised that my presence in a conversation like this might make it difficult for the National Government to feel comfortable issuing me another visa. Ever. But that was crazy; nobody was going to report this conversation to anyone in the National Government, least of all me. Method. Courtesy?

I could not help myself. Fellas, I said, the Government of Papua New Guinea is not going to let New Ireland go just because a majority of people vote to leave, even if it ever got to a vote. The mine at Lihir alone is worth an awful lot to them; they are not going to just abandon all claims to it. 'Armed rebellion, then', one man countered. I shook my head. So much for courtesy. What about method? Who were they to me now? Tough economic times (the value of the kina was about one-third in 2003 of what it had been in 1992) and the prospects of vanilla had made for radical, high-risk/high-reward thinking - or if not thinking, then reflexes. Who was I to them now? Well, when it came to conversations in the same secessionist vein, it was clear who I was to them: party pooper. And what had I become? Could I, in that moment, have been considered any kind of ethnographer by anyone?

In 2005, I returned to find out that the Great Vanilla Project had not turned out well at all. Apparently, buyers had little interest in the first vanilla harvestssomething about the soil's acidity. Vanilla vines still received some attention, but the thrill was gone. I was disappointed, too. What little I knew about vanilla was consistent with the idea that it would be a successful cash crop on New Ireland, and I had been excited about the possibilities. As I mentioned above, this was not the first local cash-crop expectation that had gone bad, so the local response was fatalistic acceptance.

Reports of the disappointment with vanilla were immediately followed with hope for the next venture: soya beans. At a men's house at nearby Nokon village, one man carefully unwrapped a soya pod from a dirty handkerchief and proudly 
showed me his ticket to economic freedom. It had cost him K5 (about US\$2), but it was a small price to pay, he said, given what the eventual pay-off would be. I was able to stifle a laugh-courtesy (barely), but method? My amusement at this man's gullibility quickly gave way to irritation. Who had exploited this poor guy's naivety? Probably some other unlucky schnook, I imagined. ${ }^{7}$ Others agreed that the future, with soya, was bright, and that they planned on planting some seeds - once the price of seeds went down.

That is a bad idea, I said. I told them that I had seen extensive soya bean fields in the United States and that farmers in the United States grew far more soya beans than they could ever sell in their own country and that they exported them all over the world. No way, I said, could New Ireland soya beans compete in such a global market. Perhaps in someone's lexicon somewhere, my efforts to warn people away from cultivating soya beans as a cash crop could be construed as an instance of courtesy, but that is a stretch. Reading disappointment on some faces, I did hurry to add that as far as I knew, soya beans were very nutritious and that, if they were able to flourish in the local soils and climate, they should make a very nice contribution to the daily diet.

Another significant moment of the 2005 field trip took place en route to Tekedan. Riding in the back of a truck with my wife, Pam, who was able to join me for this trip, I was told that my friend Topiknat (not a pseudonym) had died a few months earlier. While he was clearing trees for a new swidden, there was an accident in which a tree trunk had somehow kicked back and struck him in the chest, killing him instantly, according to his widow.

Topiknat was a weekend neighbour at Tekedan village in 1989-92 and 1998. He worked as a tradesman for the Department of Public Works at the town of Namatanai, a couple of hours' drive north. At that time, he stayed in town during the working week, but retired in 2000 and returned to village life, and we enjoyed many pleasant conversations in 2002 and 2003. Affable, smart, welleducated and universally well-liked, he had begun to fill the leadership vacuum caused by the deaths of the two most respected male leaders in 1998 (Topakta, mentioned above) and 1999. His death was a profound setback to his family as well as to Tekedan village - and to me. In 2003, at a farewell gathering on the evening before my departure, he gave a short speech that was something of a

7 I do not want to give the impression that the folks on New Ireland are simpletons. In 1991, a men's house discussion at Tekedan about the dramatic political and economic changes occurring in Eastern Europe took place. The conversation was centred on whether, and the degree to which, the change to capitalist economies would eventually result in greater amounts of disposable income for the citizens of those countries. Increased disposable income would almost certainly be used to purchase more chocolate, the argument proceeded, which would increase cacao prices. The question was how many more cacao trees should be planted tomorrow and next week in order to have an increased number of bearing trees a few years from now when these economies hit their stride, Notice that the 'chocolate futures' conversation took place a decade before the K5 soya bean purchase, so one cannot conclude a greater economic expertise over time. 
tribute to me - I was one of Tekedan's own he had said, like a kinsman who lived in Port Moresby and whose return trips to the village were all too infrequent but always sure and welcomed. I was flattered and carefully inspected the tops of my own feet as he spoke. I could not know, of course, that it was the last time I would ever see Topiknat.

Protocol in the wake of someone's death required a gift of food to Topiknat's widow, Eriel. We walked to the house and Pam, long since assigned to Topiknat's matrimoiety, sat with Eriel and the two keened as they would have had we been present for the funeral months earlier. My role as a male was to sit nearby and look sad-simple enough; courtesy and method were together again, but not in the usual way. Here, method had provided, over the years, a familiarity with what was expected of me. This led to an easy-to-follow set of expectations for what constituted courtesy in that situation. Who was I to Eriel? Who was she to me? What had I become? Was I an ethnographer in that moment? Clearly, having been an ethnographer there made my expressions of grief locally appropriate. Method had contributed to courtesy rather than, as I had often imagined it previously - and as Don meant it? - the causal arrow pointing the other way. Either way, courtesy and method were becoming more and more unrelated the more time I spent on New Ireland. I could identify times in which I found myself courteous but devoid of method, while at other times engaging in ethnography but with a brusque frankness never far from the surface. I do not remember myself having been that way in 1990. Did they?

Tohom died in December 2008. I am sure that he died believing that Towor was behind his illness. I had hoped to be in the field for a mortuary feast in his honour, but I was not able to make it back until after the second and largest feast in the sequence had taken place. As his 'brother', I would have been expected to contribute to the cost of that feast. This would probably have cost me at least a couple of hundred dollars, but I would have wanted to do it. Courtesy and method were irrelevant as I contemplated the activities surrounding that feast, and the concerns of who I was to them and who they were to me were blunted by grief over the loss of my friend. That loss was felt ever so much more profoundly when I was there in 2009.

In 2009, I arrived back on New Ireland a month after Towor and his wife diedon the same day. This coincidence was quite salient locally and people talked with me as if it had happened just days earlier. In a world where there are perceived to be very few coincidences, these twin deaths were considered to have significant meaning. What that meaning might have been was still being discussed. Towor's reputation as a sorcerer was, naturally, central to many of the interpretations, but now Towor's wife, my 'mother', was also indicted posthumously as someone who used this sort of knowledge for ill. I felt obliged to defend Towor out of some sort of respect-for-the-dead protocol, but I knew 
that my protestations would ring hollow. After all, waitskins do not really understand how sorcery works, so what I said did not matter much. Although I was motivated to say only positive things about Towor, I cannot say that that motivation had much to do with concerns of either courtesy or method. Even as I write this, I wonder about who I had become to Towor in our estrangement. And in a final irony, one of the last things I did during my 2009 field trip was attend the mortuary feast for Towor.

One New Ireland morning in January 2010, I was greeted by Tinkai, who, with her husband, often brought me a kettle of heated water so that we could sit and drink coffee. 'You don't sleep with your windows open, do you?' she asked. When I said that I do, she then asked if I had seen the sirmát the previous night. It took me a moment or two to remember that a sirmát is a long-haired female forest spirit that sneaks into villages at night. She is not dangerous, but she does things such as seduce men and put her own infant next to a nursing mother in order to have her child fed well. Tinkai related how her twentyfive-year-old son, Tohol, spent half the night chasing a sirmát through Tekedan village. As if on cue, Tohol stopped by and regaled me with the account of how he went, flashlight in hand, from this house to that, occasionally catching a fleeting glimpse of her.

Now, Tohol has completed Grade 10 and has worked at the Lihir mine, so he is not a rube. I had already started thinking about and writing this chapter and it was no great epiphany to wonder if this was my Nambweapa'w. While a sirmát is no Nambweapa'w in terms of cultural salience, here was my chance to be courteous and not disabuse, as well as to utilise the opportunity to learn more about sirmáts. Instead, I sceptically grilled Tohol on whether he had actually seen anything, whether the moon had set by the time he began conducting his search, and if anyone else had seen anything. He was unaffected by my doubt - indeed, he might not have even noticed. In the aftermath of that conversation, I felt a sadness. Who was I to Tohol and his family? And what kind of anthropologist actively works to undermine a belief in sirmáts? This kind of wistfulness is different, however, from the grief that 20 years of acquaintance with the Sursurunga people has engendered.

I grieve about the leadership vacuum at Tekedan caused by Topiknat's death. I fret about what will take the place of soya beans in the latest get-rich-quick scheme. I worry about the implications of the talk of secession. I think about my friend Tohom's debilitating illness and death, as well as Towor and our estrangement. I reflect on who else's death I will hear about when I arrive.

I puzzle over why I feel more free to give my views about things nowadays - that is, why, in some respects, I seem to exercise less courtesy than I did in the past on New Ireland. Perhaps it is one of the signs of the onset of a cantankerous dotage. 
Clearly, I am not the rookie ethnographer of 1989 with his young family in tow, and I wonder whether all fieldworkers experience the life cycle in the same way that I have vis-a-vis a community in another part of the world. It is obvious that the demographic profile of an anthropologist in the field affects the nature of her or his experience - and therefore of the results, but this is a different question. Things have changed between them and me, and I know that it is not only the perception of things, but also the memories - mine as well as theirs - of what has transpired between us. James Clifford might have captured it when he writes that '[i]n ethnography, what was previously understood in terms of rapport - a kind of achieved friendship, kinship, empathy - now appears as something closer to alliance building. The relevant question is less: "What fundamentally unites or separates us?" and more: "What can we do for one another in the present conjuncture?"' (1997:87, emphases in original). While this represents Clifford's understanding of the historical change in the epistemological stance of the fieldworking anthropologist that occurred during the second half of the twentieth century, it also captures the ontogenetic alteration in the character of my relationship with the Sursurunga people of southern New Ireland. Perhaps the former question had been wordlessly, implicitly answered and on both sides the relationship had moved to being characterised by the latter question. Certainly, this goes a long way towards describing the difference, but it does not explain how it happened, nor does it shed any light on whether the movement from one question to the other occurred simultaneously on both sides. Tuzin's phrase 'the self finding itself in memory' captures the phenomenon as well as any other, with the reminder that memories are contingent and continuously reformulated. The people of the area on New Ireland where I work first became acquainted with me before I became middle-aged, which is how they know me now. Who have they become to me? The answer is many things, but one thing that can be said is that they are no longer players in a civility-for-data exchange. Who have I become to them? That is impossible to say, but I do know that to myself, I have become someone for whom courtesy and method are no longer linked. Or at least no longer linked in the way they used to be.

There is something else to courtesy, method and the ever-shifting understanding of an anthropologist on the part of a community and vice versa. Perhaps it is the kind of thing people say that determines an appropriate (lack of) response. In 1969, Tuzin's response to the Nambweapa'w tale was to say nothing, as was mine many times, including to Tohom when he told me of his fear of Towor's prowess when it came to sorcery, and how he never slept in the same place on consecutive nights. Local ideas of political or economic content, on the other hand, seem to invite, perhaps by their very nature, an interlocutor's engagement in a way that local ideas about the unseen world do not. Just maybe, my input on secession was desired, and my advice on soya beans was wanted. But did 
my misgivings about the sirmát cross an invisible line? Or does that line exist only in my head because of what I take to be le pensée sauvage, and distinguish between that and those matters in which I believe myself more experienced?

There are, certainly, other features of a long-term relationship between an ethnographer and the community to which she or he returns that I have not attended to. And the metamorphosis in courtesy and method that I have described in the relationship between myself and the people in and around Tekedan village must necessarily depend on many factors including changes in the answers to 'who am I to them?' and 'who are they to me?'. But Don Tuzin's experience as described in The Cassowary's Revenge represents just how enmeshed-Herzfeld uses the more morally charged term 'complicit' (2001:25) - an anthropologist can become in local affairs.

Don's entanglement in Ilahita's events can, in some respects, be viewed as utterly inadvertent, and yet it is clearly his show of uncritical acceptance of the Nambweapa'w account back in 1969 that set in motion - or maybe better said kept from being stillborn - the events of 1984-86. It was his attention to and concern for courtesy and method that made him responsible for the eventual denouement of the Tambaran. He could have done nothing else, of course. And he was no more 'complicit' — although in some ways, yes, ultimately responsible - than were Wilbur and Orville Wright for 11 September.

When I think about my next departure for New Ireland, I think about these changes in courtesy and method as well as the way in which the folks on New Ireland are continuously reinvented in my mind, just as I am certain that I am reinvented in theirs - if not right now then surely when I arrive. Throughout this essay, I have signalled, with Tuzin's phrase, my sense of what I have become to - or, perhaps better, how I fit into - the people and events of New Ireland. At times in the course of my fieldwork, I left things unsaid, feeling now and then mildly thwarted because I wanted to say something but knew that probably I should not. At other times, though, I was glad to have the twin excuses of courtesy and method to keep my thoughts to myself since I was not sure what was appropriate anyway. And of course there were times when attention to courtesy and method - at least that kind demonstrated by Don upon first hearing the tale of Nambweapa'w - was in short supply, as with sirmáts. Through all of this, I have been inadvertently constructing a set of memories of me on New Ireland, sometimes quiet and acquiescing to what is being said while at other timesmore and more, seemingly - serving as a wet blanket to hopes and dreams, and as a purveyor of heterodoxy.

Consideration for courtesy and method certainly facilitates the ethnographic endeavour - perhaps almost by definition, at least at the outset. But with time and repeated interactions and the reconstruction of memories, this can also move 
the ethnographer towards a category that is different from the one occupied upon first arrival. Examples of this movement - and it will not be inaccurate to refer to them as method-are that talk of soya beans and talk of secession were not data-nor was sirmát scepticism. To me, these conversations were not ethnographic moments, and I did not treat them as such. I cannot say (but wonder) if local people saw me in a profoundly different way, as having become someone or something else - not as an ethnographer-and whether they have meaningful memories of me as someone who has forsaken courtesy and method.

To be sure, courtesy and method are not what they once were for me. When I am on New Ireland, I speak my mind more than I used to, but I do not think I have been rude. And I have conversations that are not ethnographic, yet they appear here in this chapter as evidence used to corroborate points I try to make. Kevin Birth (Personal communication) suggests that another way to express the transformation experienced by ethnographers who keep going back is to paraphrase Tuzin's concept of 'self finding itself in memory' by noting that an ethnographer returning to the same community over a long period is a matter of 'the self finding itself in relationship to methodology'.

Perhaps this is the best way to say it. An anthropologist who keeps returning to the same group of people (although, like Heraclitus's river, it cannot ever really be the same) becomes something very much more than a mere ethnographer. Tuzin's experience in Ilahita is an extreme case, but it is no different in kind from what anyone experiences in returning. What an anthropologist eventually becomes vis-a-vis a community is the result of a negotiation with method. How one conducts oneself in the course of ethnographic fieldwork produces - in ways that are unpredictable and often unknowable - who one becomes.

\section{References}

Barr, Abigail Margaret (Corresponding Author), Jean Ensminger, Joe Henrich, Chris Wallace, H. Clark Barrette, Juan-Camilo Cárdenas, Michael Gurven, Edwins Gwako, Carolyn Lesorogol, Frank Marlowe, Richard McElreath, David Tracer and John Ziker 2009. Homo AEqualis: A Cross-Society Experimental Analysis of Three Bargaining Games. Documento CEDE No. 2009-09, <http:// ssrn.com/abstract $=1485862>$

Berbesque, Collette, Frank Marlowe, Clark Barrett, Alexander Bolyanatz, Michael Gurvin and David Tracer (in press). The 'Spiteful' Origins of Human Cooperation. Proceedings of the Royal Society $B$. 
Bolyanatz, Alexander H. 1994. Matriliny and Mortuary Feasting among the Sursurunga of New Ireland, Papua New Guinea. Unpublished PhD Dissertation. University of California, San Diego.

Bolyanatz, Alexander H. 1998. Economic Cooperatives, Development, and Matriliny in Papua New Guinea. Notes on Anthropology 2:31-49.

Bolyanatz, Alexander H. 2000. Mortuary Feasting on New Ireland: The Activation of Matriliny among the Sursurunga. Westport, Conn.: Bergin \& Garvey.

Bolyanatz, Alexander H. 2010. Does the Use of Money Affect Results in Experimental Games?: Comparing Cash and Betel Nut in Dictator and Ultimatum Games on New Ireland. In J. Franklin, K. A. McElhanon and G. Reesink (eds), A Mosaic of Languages and Cultures: Studies Celebrating the Career of Karl J. Franklin, pp. 327-50. Dallas: SIL International.

Clifford, James 1997. Routes: Travel and Translation in the Late Twentieth Century. Cambridge, Mass.: Harvard University Press.

Fessler, Daniel M. T., D. Nettle, Y. Afshar, I. de Andrade Pinheiro, A. Bolyanatz, M. Borgerhoff Mulder, M. Cravalho, T. Delgado, B. Gruzd, M. Oliveira Correia, D. Khaltourina, A. Korotayev, J. Marrow, L. Santiago de Souza and A. Zbarauskaite 2005. A Cross-Cultural Investigation of the Role of Foot Size in Physical Attractiveness. Archives of Sexual Behavior 34:267-76.

Henrich, Joseph, Richard McElreath, Abigail Barr, Jean Ensminger, Clark Barrett, Alexander Bolyanatz, Juan Camilo Cardenas, Michael Gurven, Edwins Gwako, Natalie Henrich, Carolyn Lesorogol, Frank Marlowe, David Tracer and John Ziker 2006. Costly Punishment across Human Societies. Science 213(5781):1767-70.

Henrich, Joseph, Richard McElreath, Abigail Barr, Jean Ensminger, Clark Barrett, Alexander Bolyanatz, Juan Camilo Cardenas, Michael Gurven, Edwins Gwako, Natalie Henrich, Carolyn Lesorogol, Frank Marlowe, David Tracer and John Ziker 2010. Markets, Religion, Community Size and the Evolution of Fairness and Punishment. Science 327:1480-4.

Herzfeld, Michael 2001. Anthropology: Theoretical Practice in Culture and Society. Malden, Mass.: Blackwell.

Marlowe, Frank W., J. Colette Berbesque, Abigail Barr, Clark Barrett, Juan Camilo Cardenas, Jean Ensminger, Michael Gurven, Edwins Gwako, Joseph Henrich, Natalie Henrich, Carolyn Lesorogol, Richard McElreath and David Tracer 2008. More 'Altruistic' Punishment in Larger Societies. Proceedings of the Royal Society B 275:587-90. 
Ranson, Gillian 2005. 'I'm Looking Forward to Hearing What You Found Out': Reflections on a Critical Perspective and Some of its Consequences. In D. Pawluch, W. Shaffir and C. Miall (eds), Doing Ethnography: Studying Everyday Life, pp. 96-125. Toronto: Canadian Scholars' Press.

Tuzin, Donald F. 1980. The Voice of the Tambaran: Truth and Illusion in Ilahita Arapesh Religion. Berkeley: University of California Press.

Tuzin, Donald F. 1997. The Cassowary's Revenge: The Life and Death of Masculinity in a Papua New Guinea Society. Chicago: University of Chicago Press. 